\title{
PENERAPAN SANKSI PIDANA TERHADAP PELAKU TINDAK PIDANA KEKERASAN SEKSUAL TERHADAP ANAK
}

\author{
Oleh: \\ Dody Suryandi ${ }^{1)}$ \\ Nike Hutabarat ${ }^{2)}$ \\ dan Hartono Pamungkas ${ }^{3)}$ \\ UniversitasDarmaAgung, Medan ${ }^{1,2,3)}$ \\ E-mail: \\ dody.suryandi.ac@gmail.com ${ }^{1)}$

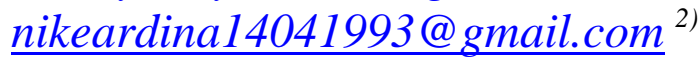 \\ dan hartonopamungkas123@gmail.com, ${ }^{3)}$
}

\begin{abstract}
Every child who is a victim in a crime of sexual violence or rape, at the trial stage the child victim must be a witness. The victim must repeat the story or incident that he experienced before the panel of judges, prosecutors of the defendant's lawyer and the defendant himself. The victim must not be positioned in a depressed state, both physically and psychologically. When the victim becomes a witness, the victim is treated as well as possible, in the sense that he must not be feared by outsiders both psychologically and psychologically.
\end{abstract}

Keyword: Penalty, Sexual Assault, Child

\begin{abstract}
ABSTRAK
Setiap anak yang menjadi korban dalam kejahatan kekerasan seksual atau pemerkosaan, pada tahap persidangan korban anak harus menjadi saksi. Korban harus mengulangi cerita atau kejadian yang dia alami di hadapan majelis hakim, jaksa penuntut dan terdakwa sendiri. Korban tidak boleh diposisikan dalam keadaan tertekan, baik secara fisik maupun psikologis. Ketika korban menjadi saksi, korban diperlakukan sebaik mungkin, dalam arti bahwa ia tidak perlu ditakuti oleh orang luar baik secara psikologis maupun psikologis.
\end{abstract}

Kata kunci: Penalti, Penyerangan Seksual, Anak

\section{PENDAHULUAN}

Perlindungan terhadap kekerasan seksual pada anak juga dilakukan dengan melakukan pencegahan, tidak hanya menghukum pelaku lalu sudah dapat dianggap memberikan keadilan pada korban tetapi juga perlu memberikan pengertian tentang bagaimana sebenarnya pelecehan seksual tersebut untuk mencegah anak-anak menjadi korban pelecehan seksual, antara lain: lingkungan keluarga, Lingkungan Sekolah,
Pemerintah. Adapun yang menjadi pokok permasalahan adalah Bagaimana Pengaturan Hukum Tindak Pidana Kekerasan Seksual terhadap Anak di Indonesia ditinjau dari Undang-Undang No.35 Tahun 2014 tentang Perlindungan Anak, Bagaimana Penerapan Sanksi Pidana terhadap Tindak Pidana Kekerasan Seksual terhadap Anak menurut UndangUndang No.35 Tahun 2014 tentang Perlindungan Anak, Bagaimana 
Pertimbangan Hukum Hakim terhadap Putusan 3551/Pid.Sus/2018/PN.Mdn?

\section{TINJAUAN PUSTAKA}

Cabul merupakan perbuatan yang menjurus ke arah perbuatan seksual atau dapat berupa perkataan dan gambar yang mengarah pada seksual yang dilakukan untuk meraih kepuasan diri diluar ikatan perkawinan.

Pelecehan seksual merupakan istilah dalam masyarakat untuk menggambarkan suatu tindak kekerasan secara seksual, sedangkan di dalam hokum istilah pelecehan seksual jarang digunakan karena lebihm enggun akan istilah kekerasan seksual kecuali dalam UndangUndang Nomor 9 tahun 1999 tentang Hak Asasi Manusia yang menyebutkan adanya istilah pelecehan seksual.

Delik kesusilaan terhadap anak-anak di dalam KUH Pidanaakan di bedakan menjadi 2 yaitu :

\section{a. Persetubuhan \\ b. PerbuatanCabul}

Perbuatan cabul pada anak bisa diorientasikan juga dengan kegiatankegiatan seksual yang verbal dan non verbal, seperti memegang bagian kemaluan seseorang, ajakan berhubungan seksual yang tidak dikehendaki korban dan ada unsur pemaksaan didalamnya.

Perbuatan cabul sendiri dalam Kitab Undang-Undang Hukum Pidana terdiri dari perbuatan cabul pada orang yang telah dewasa, anak-anak dan pada yang sejenis, perbuatan cabul pada orang dewasa diatur dalam Pasal 281, 282, 283, 283 bis, 284 dan 286.

Perbuatan cabul pada anak-anak diatur dalam Pasal 287, 288, 289, 290 dan 291 sedangkan perbuatan cabul pada sesama jenis diatur dalam pasal 292 dan 293, adanya pasal 292 dan 293 menunjukan bahwa perbuatan pelecehan seksual yang masuk katagori perbuatan cabul tidak hanya berlangsung antara lakilaki dan perempuan saja akan tetapi juga terhadap yang sejenis.
Sanksi hukuman terhadap pelaku kekerasan seksual terhadap anak yang masih di bawah umur telah diatur sendiri di dalam Undang-Undang Perlindungan Anak Nomor 35 Tahun 2014 tentang Perubahan Undang-Undang Perlindungan Anak Nomor 23 Tahun 2002 Pasal 81 Butir (1), (2), (3).

Pemberian sanksi hukuman tambahan terhadap pelaku kejahatan pemerkosaan terhadap anak yang masih di bawah umur harus dilakukan, agar mampu memberikan efek jerabagi pelaku.

Ada 4 masalah anak yaitu :

1) Kekerasan pada mental,

2) Kekerasan pada jasmani,

3) Kekerasan di sekolah, dan

4) Kekerasan pada seksual

\section{METODE PENELITIAN}

Metode pendekatan yang dilakukan dalam penelitian ini adalah metode yuridis normatif, yaitu Penelitian Hukum yang dilakukan dengan carameneliti bahan pustaka atau data sekunder, bempa hokum positif dan bagaimana penerapannya dalam praktik di Indonesia.

\section{HASIL dan PEMBAHASAN}

a. Pengaturan Hukum Tindak Pidana Kekerasan Seksual Terhadap Anak Di Indonesia Ditinjau Dari Undang-Undang Nomor. 35 Tahun 2014 Tentang Perlindungan Anak

Persetubuhan dalam Buku II Bab XIV KUH Pidana tentang Kejahatan Terhadap Kesusilaan. Kejahatan ini diartikan sebagai perbuatan pidana berkaitan dengan seksualitas yang dapat dilakukan terhadap laki-laki ataupun perempuan. Persetubuhan dibagi menjadi beberapa macam yaitu :

1. Persetubuhan dengan paksaan diatur dalam Pasal 285 KUH Pidana. 
2. Persetubuhan tanpa paksaan diatur dalam 286 dan 287 KUH Pidana.

3. Persetubuhan terhadap anak diatur dalam Pasal 289 KUH Pidana.

Pelecehan seksual pada anak tidak hanya diatur dalam Kitab Undang-Undang Hukum Pidana saja tetapi juga diatur dalam peraturan yang lebih khusus yaitu diatur dalam Undang-Undang Nomor 35 tahun 2014 tentang Perlindungan Anak pada Pasal 81 dan 82 yang menyebutkan bahwa : hukuman bagi pelaku kejahatan seksual terhadap anak minimal 5 tahun dan maksimal 15 tahun penjara serta denda minimal maksimal sebesar Rp. 5.000.000.000,00 (lima miliar rupiah, sedangkan hukuman lainnya menurut KUHP pasal 287 dan 292 menyebutkan bahwa masa hukuman terhadap pelaku pencabulan terhadap anak maksimal 9 tahun (pasal 287) dan maksimal 5 tahun (pasal 292) hal ini menunjukan bahwa 53 undang-undang perlindungan anak sebagai lex specialis memberikan ancaman yang lebih besar dibanding dengan yang diatur dalam KUHP.

Ketentuan tersebut terdapat di dalam Pasal 80 ayat (1), (2), dan (3) sebagaimana tersebut di bawah ini:

Setiap orang yang melanggar ketentuan sebagaimana dimaksud dalam pasal 76C yang berbunyi :

1. Setiap orang dilarang menempatkan, membiarkan, melakukan, menyuruh melakukan, atau turut serta melakukan kekerasan terhadap anak. Dipidana dengan pidana penjara paling lama 3 (tiga) tahun 6 (enam) bulan dan/atau denda paling banyak Rp 72.000.000,00 (tujuh puluh dua juta rupiah).

2. Dalam hal anak sebagaimana dimaksud dalam ayat (1) luka berat, maka pelaku dipidana dengan pidana penjara paling lama 5 (lima) tahun dan/atau denda paling banyak $\mathrm{Rp}$ 100.000.000,00 (seratus juta rupiah).
3. Dalam hal anak sebagaimana dimaksud pada ayat (2) mati, maka pelaku dipidana dengan pidana penjara paling lama 15 (lima belas) tahun dan/atau denda paling banyak $\mathrm{Rp}$ 3.000.000.000,00 (tiga miliar rupiah).

Dalam Pasal 80 ayat (4) UndangUndang No. 35 Tahun 2014 tentang Perlindungan Anak juga mengatur secara khusus mengenai tidak pidana penganiayaan terhadap anak dalam keluarga disertai sanksi pidana yaitu:

Pidanaditambah 1/3 (sepertiga) dari ketentuan sebagaimana dimaksud dalam ayat (1), ayat (2), dan ayat (3) apabila yang melakukan penganiayaan tersebut adalah orang tuanya. Adapun kewajiban dan tanggung jawab negara dan pemerintah terhadap penyelenggaraan perlindungan anak, ditegaskan dalam Pasal 21 sampai Pasal 25 UU No. 35 Tahun 2014 tentang Perlindungan Anak, yang meliputi kewajiban dan tanggungjawab.

Bentuk perlindungan anak yang diberikan oleh Undang-Undang Perlindungan Anak dan Undang-Undang Penghapusan Kekerasan Dalam Rumah Tangga dan Sistem Peradilan Pidana Anak merupakan adopsi, kompilasi, atau reformulasi dari bentuk perlindungan anak yang sudah diatur dalam Kitab UndangUndang Hukum Pidana. Dalam KUHP terdapat beberapa pasal yang memberikan perlindungan bagi anak terhadap kekerasan seksual, perlindungan terhadap anak ditunjukkan dengan pemberian hukuman (sanksi) pidana bagi pelaku.

Hal ini tercantum dalam KUHP pada pasal-pasal dalam sebagai berikut:

1. Masalah pesetubuhan diatur dalam Pasal 287, Pasal 288, Pasal 291

2. Perbuatan cabul diatur dalam Pasal 289, Pasal 292, Pasal 293, Pasal 294, Pasal 295, Pasal 298.

Jadi bentuk perlindungan hukum yang diberikan KUHP bagi anak terhadap kekerasan seksual merupakan 
pertanggungjawaban pidana terhadap pelaku, bukanlah pertanggung jawaban terhadap kerugian/penderitaan korban secara langsung dan konkret, tetapi lebih tertuju pada pertanggungjawaban yang bersifat pribadi/individual.

Berikutnya dalam Undang-Undang No. 23 Tahun 2002 tentang Perlindungan Anak sebagaimana yang telah diubah dengan Undang-Undang Nomor 35 Tahun 2014 tentang Perubahan Atas UndangUndang Nomor 23 Tahun 2002 tentang Perlindungan Anak juga memberikan perlindungan bagi anak yang diatur. Undang-undang ini berfungsi untuk pemberian perlindungan khusus bagi hakhak anak dari berbagai macam kekerasan dalam hal ini tindak kekerasan seksual. Secara tegas dalam Pasal 15 UndangUndang Nomor 35 Tahun 2014 tentang Perubahan Atas Undang-Undang Nomor 23 Tahun 2002 tentang Perlindungan Anak menyebutkan bahwa: "Setiap Anak berhak untuk memperoleh perlindungan" dari:

a. Penyalahgunaan dalam kegiatan politik;

b. Pelibatan dalam sengketa bersenjata ;

c. Pelibatan dalam kerusuhan sosial ;

d. Pelibatan dalam peristiwa yang mengandung unsure kekerasan ;

e. Pelibatan dalam peperangan; dan

f. Kejahatan seksual.

Bentuk- bentuk penegakah hukum terhadap tindak pidana $\mathrm{p}$ seksual pada anak dalam Kitab Undang-Undang Hukum Pidana (KUHP) dan Undang-Undang Perlindungan Anak Nomor 23 Tahun 2002 telah dijelaskan bahwa tindak pidana pelecehan seksual terhadap anak di bawah umur merupakan sebuah kejahatan kesusilaan yang bagi pelakunya harus diberikan hukuman yang setimpal. Maksud dan tujuannya agar dengan dijatuhkan hukuman kepada pelaku dapat mengurangi dan mencegah terjadinya pelanggaran hukum dari kejahatan seksual pada anak.

\section{b. Penerapan Sanksi Pidana Terhadap PelakuTindak Pidana Kekerasan SeksualTerhadap Anak} Pasal 81 berbunyi :

Setiap orang yang dengan sengaja melakukan kekerasan atau ancaman kekerasan memaksa anak melakukan persetubuhan dengannya atau dengan orang lain, dipidana dengan pidana penjara paling lama 15 (lima belas) tahun dan paling singkat 3 (tiga) tahun dan denda paling banyak Rp. 300.000.000,00 (tiga ratus juta rupiah) dan paling sedikit $\mathrm{Rp}$. 60.000.000,00 (enam puluh juta rupiah).

(1) Ketentuan pidana sebagaimana dimaksud dalam ayat (1) berlaku pula bagi setiap orang yang dengan sengaja melakukan tipu muslihat, serangkaian kebohongan, atau membujuk anak melakukan persetubuhan dengannya atau dengan orang lain

Pasal 82 berbunyi :

Setiap orang yang dengan sengaja melakukan kekerasan atau ancama kekerasan, memaksa, melakukan, tipu muslihat, serangkaian kebohongan, atau membujuk anak untuk melakukan atau membiarkan dilakukan perbuatan cabul, dipidana dengan pidana penjara paling lama 15 (lima belas) tahun dan paling singkat 3 (tiga) tahun dan denda paling banyak Rp. 300.000.000,00 (tiga ratus juta rupiah) dan paling sedikit Rp. 60.000.000,00 (enam puluh juta rupiah).

Tindak pidana kekerasan seksual terhadap anak merupakan masalah yang sangat serius. Kekerasan seksual terhadap anak tidak hanya akan menimbulkan dampak yang secara fisik tetapi juga dampak secara mental.

Dampak secara fisik tidak membutuhkan waktu yang terlalu lama untuk mengobatinya, tetapi dampak secara mental bias membutuhkan waktu bertahuntahun agar dapat pulih seperti sediakala. Bahkan, ada juga yang sampai mengalami masalah kejiwaan atau depresibahkan 
sampai memutuskan bunuh diri dikarena tidak kuat menahan penderitaan dan rasa maluakibat pelecehan seksual yang dialaminya.

Sistem Peradilan Pidana adalah sistem yang dibuat untuk menanggulangi masalah-masalah kejahatan yang dapat mengganggu ketertiban dan mengancam rasa aman dalam suatu masyarakat.

Bahwa kata system menunjukkan adanya suatu kesan dari objek yang komplekslainny adan berjalan dari awal sampai akhir, oleh karena itu dalam mewujudkan tujuan system tersebut ada empatinstansi yang terkaityaitu Kepolisian, Kejaksaan, Pengadilan dan Lembaga Pemasyarakatan.

Keempat komponen tersebut harus bekerjasama secara terpadu. Berproses secara terpadu artinya keempat sub sistemini berkerjasama berhubungan walaupun masing-masing berdiri sendiri.

Polisi selaku penyidik melakukan penyidikan termasuk penyelidikan, penangkapan, penahanan, penggeledahan dan penyitaan. Jaksaselaku penuntutumum melakukan penuntutan berdasarkan hasil penyidikan yang disampaikan oleh penyidik. Hakim atas dasar dakwaan penuntutumum mengadili dalam persidangan.

Setiap anak yang menjadi korban dalam tindak pidana kekerasan seksual atau perkosaan, pada tahap persidangan anak yang menjadi korban tersebut harus menjadi saksi. Si korban harus mengulangi cerita atau kejadian yang telah dialaminya dihadapan majelis hakim, jaksa dari pengacara terdakwa serta terdakwa itu sendiri. Si korban tidak boleh diposisikan dalam keadaan tertekan, baik fisik maupun psikisnya.

Pada saat korban menjadi saksi, korban tersebut diperlakukan dengan sebaik mungkin, dalam arti dia tidak boleh ditakuti oleh pihak luar baik psikologis maupun psikisnya.
Ketika korban itu berangkat ke Pengadilan, apabila ada upaya melakukan intimidasi terhadap pihak korban maupun keluarga korban. Korban ditempatkan diruangan tersendiri, yang nantinya tidak boleh ada pihak-pihak yang menakutiatau melakukan intimidasi kepada korban, bilamana perlu ada pengawasan dari petugas pengadilan, kejaksaan, kepolisian.

\section{c. Pertimbangan Hukum Hakim Terhadap Putusan Perkara Nomor 3551/Pid.Sus/2018/PN.Mdn}

Menimbang, bahwa berdasarkan fakta-fakta di persidangan akan di pertimbangkan apakah terdakwa terbukti bersalah melakukan tindak pidana sebagaimana yang di dakwaan jaksa penuntut umum.

Menimbang bahwa terdakwa di hadirkan di persidangan berdasarkan surat dakwaan penuntut umum disusun secara alternatif, Kesatu didakwa melanggar pasal 81 ayat (1) Jo pasal 76D Undang-Undang RI no.35 Tahun 2014 tentang perlindungan anak, Kedua melanggar pasal 81 ayat (2) Jo pasal 76D Undang-Undang RI no.35 Tahun 2014 tentang perlindungan anak, Ketiga pasal 82 ayat (1) Jo pasal 76E Undang-Undang RI no.35 Tahun 2014 tentang perlindungan anak.

Menimbang bahwa oleh karena dakwaan penuntut umum disusun secara alternatif maka majelis hakim langsung memilih dakwaan yang paling sesuai dengan perbuatan terdakwa berdasarkan fakta-fakta yang terungkap dalam persidangan dan menurut majelis hakim dakwaan yang paling sesuai dengan perbuatan terdakwa adalah dakwaan Ketiga melanggar pasal 82 ayat (1) Jo pasal 76E Undang-Undang RI no.35 Tahun 2014 tentang perlindungan anak yang unsur-unsur nya :

a) Setiap orang

b) Melakukan kekerasan atau ancaman kekerasan, memaksa, melakukan tipu mulsihat, serangkain kebohongan atau 
membujuk anak untuk melakukan atau membiarkan perbuatan cabul dengan nya atau dengan orang lain.

Mengenai Unsur Setiap Orang, Menimbang, bahwa yang dimaksud dengan setiap orang dalam perkara ini adalah siapa saja selaku manusia sebagai subjek hukum yang di dakwa melakukan suatu tindak pidana tanpa terkecuali diri terdakwa Julkarnaen Batubara Alias DEKOK yang dituntut serta diminta pertanggungjawaban atas perbuatannya.

Menimbang bahwa yang dengan diajukan nya terdakwa ke persidangan dalam perkara ini identitas nya sebagai mana tercantum secara jelas dan lengkap dalam surat dakwaan penuntut umum, hal mana telah dibenarkan saksi-saksi dan terdakwa dan selama persidangan terdakwa dapat menjawab secara baik dan lancar atas pertanyaan yang diajukan kepadanya, sehingga orang yang didakwa melakukan tindak pidana sebagaimana dalam dakwaan penuntut umum tidak keliru diajukan ke persidangan dan terdakwa dapat diminta pertanggungjawaban atas perbuatannya, maka dengan demikian unsur setiap orang telah terpenuhi.

Hal-Hal Yang Diperhatikan Dalam Pertimbangan Halam Dalam Putusan PerkaraNomor.3551/Pid.Sus/2018/PN.MD N. Selain mempertimbangkan hal-hal yang meringankan dan memberatkan terdakwa, hakim juga mempertimbangkan hal yang berkaitan dengan kesalahan yang dilakukan oleh terdakwa. Kesalahan dibagi menjadi dua bagian yaitu kesengajaan dan kealpaan. Dalam kasus ini jelas bahwa terdakwa melakukan perbuatannya dengan sengaja, oleh karena itu terpenuhilah unsur kesalahannya. Dalam kasus ini sikap batin dari pelaku saat melakukan perbuatannya tidak dalam keadaan dipaksa, tertekan atau dalam pengaruh obat-obatan, artinya pelaku secara sadar melakukan perbuatannya.

Dalam hal ini hakim tidak mempertimbangkan motif sebenarnya dari pelaku karena dalam kesaksiannya pelaku tidak hanya menunjukkan alat kelamin terdakwa kepada korban tapi juga sempat memasukkan jari kedalam kemaluan dari korban yang bisa saja tujuan dari pelaku adalah ingin memperkosa korban. Hakim mempertimbangkan bagaimana terdakwa melakukan perbuatannya tersebut, karena dengan mengetahui cara yang dilakukan terdakwa tersebut hakim dapat mengetahui apa saja yang terjadi sehingga dapat menjadi pertimbangan hakim dalam menjatuhkan hukuman terhadap terdakwa. Dalam hal-hal yang meringankan, hakim mempertimbangkan usia terdakwa yang sudah lanjut usia serta mempertimbangkan sikap terdakwa setelah perbuatannya tersebut dilakukan yaitu terdakwa mengakui dan menyesali perbuatannya dan telah meminta maaf kepada keluarga korban dipersidangan namun hakim tidak mempertimbangkan apakah perbuatan terdakwa telah dimaafkan oleh korban sebagai salah satu pertimbangannya. Dalam hal-hal yang memberatkan terdakwa, penulis berpendapat bahwa hakim lebih menitik-beratkan pada perbuatan terdakwa, yaitu perbuatan terdakwa meresahkan masyarakat dimana anak yang masih dibawah umur sebagai korban dari tindak kekerasan seksual.

\section{KESIMPULAN dan SARAN}

1. Pengaturan tentang persetubuhan terhadap anak diatur dalamUndangUndang Perlindungan Anak Nomor.35 Tahun 2014Pasal 81 dan 82 ayat (1), (2),dan(3)Undang-Undang

Perlindungan Anak Nomor.35 Tahun 2014. Tentang tindak pidana kekerasan seksual terhadap anak pada pasal 76D, 76E dan dalam KHUP terdapat juga beberapa pasal yang memberikan perlindungan bagi anak terhadap kekerasan seksual, perlindungan terhadap anak ditunjukkan dengan pemberian hukuman(sanksi) pidana, bagi pelaku 
yaitu : pada pasal 287, 288, 291 yang mengatur tentang persetebuhan. Sedangkan perbuatan cabul/kekerasan seksual terhadap anak diatur dalam pasal 289, 292, 293, 294, 295, dan 298.

2. Penerapan Sanksi hukum pidana materil terhadap pelaku tindak pidana kekerasan seksual terhadap anak Nomor.3551/Pid.Sus/2018/PN.MDN, yaitu didasarkan pada fakta-fakta hukum baik melalui keteranganketerangan saksi, keterangan terdakwa, maupun alat-alat bukti. Selain itu, juga didasarkan pada pertimbangan yuridis yaitu dakwaan dan tuntutan jaksa. Dalam kasus ini, jaksa menggunakan dakwaan ketiga yaitu penuntut umum mendakwakanmelanggar pasal 82 ayat (1) Jo pasal 76E Undang-Undang RI no.35 Tahun 2014 tentang perlindungan anak. Menjatuhkan pidana penjara terhadap terdakwa selama 10 Tahun dan pidana denda sejumlah Rp. 600.000.000,-

(Enam Ratus Ribu Rupiah) dengan ketentuan jika denda tersebut tidak dibayar maka harus diganti dengan pidana kurungan selama 3 Bulan.

3. Pertimbangan Hakim dalam putusan disertai dengan pertimbangan, baik pertimbangan yang memberatkan terdakwa maupun pertimbangan yang meringankan terdakwa. Hal ini diatur dalam pasal 197 ayat (1) huruf F Kitab Undang-Undang Hukum Acara Pidana. Dasar pertimbangan hakim dalam menjatuhkan pidana terhadap pelaku tindak pidana kekerasan seksual terhadap anak dalam Putusan Nomor 3551/Pid.Sus/2018/PN.MDN telah memperhatikan dasar mengadili, dasar memutus, dan nilai-nilai yang hidup dalam masyarakat, kemudian telah mempertimbangan pertimbangan yuridis. Secara yuridis berdasarkan dakwaan penuntut umum, keterangan saksi, surat dan keterangan terdakwa dan non yuridis berdasarkan hal-hal yang memberatkan dan meringankan, telah memperhatikan unsur-unsur dalam pasal 82 ayat (1) Jo pasal 76E Undang-Undang no.35 Tahun 2014tentang perlindungan anak. Menjatuhkan pidana penjara terhadap terdakwa selama 10 Tahun dan pidana denda sejumlah Rp. 600.000.000,(Enam Ratus Ribu Rupiah) dengan ketentuan jika denda tersebut tidak dibayar maka harus diganti dengan pidana kurungan selama 3 Bulan. Seorang Hakim dalam menjatuhkan putusan harus mempertimbangakan hukum yang ada dimasyarakat sesuai dengan Undang-undang kekuasaan kehakiman.

1. Seharusnya dengan dilakukannya perubahan/revisi undang-undang perlindungan anak, kiranya dapat memberikan efek jera terhadaap pelaku sehingga dapat menanggulangi tindak kekerasan seksual terhadap anak di Indonesia mengingat perubahan yang terjadi lebih memperberat sanksi (hukuman). Sanksi hukuman kebiri sebenarnya harus lebih ditujuhkan kepada pelakupelaku tindak pidana terhadap anak, dan bisa lebih dijalankan, untuk membuat efek jera bagi para pelakupelaku tindak pidana terhadap anak, tapi sejauh ini penulis belum bisa melihat sanksi kebiri berjalan dengan baik.

2. Seharusnya Penengak Hukum lebih memperkuat sanksi (hukuman) untuk mengurangi tindak pidana terhadap anak terlebih tindak pidana kekerasan seksual terhadap anak.Karena efek yang diterima anak sebagai korban ialah trauma yang mendalam, serta hilangnya rasa kepercayaan diri anak yang telah disetubui oleh para pelaku karena telah merebut kesucian anak dan merusak masa depan si anak.

3. Seharusnya Hakim menjatuhkan hukuman kepada pelaku kekerasan seksual dengan melihat keadaan 
korban yaitu si anak bagaimana ia terguncang dengan kejadian yang telah diperbuat pelaku. Dengan kata lain, Hakim harus memberikan sanksi yang seberat-beratnya kepada para pelaku kekerasan kepada anak terlebih pada kasus seksual terhadap anak supaya dapat menimbulkan efek jera kepada para pelaku dan menghindari terjadinya lagi kasus-kasus kekerasan seksual kepada anak-anak yang masih dibawah umur.

\section{DAFTAR PUSTAKA}

Marpaung, Leden, Proses Penanganan Perkara Pidana, Jakarta, Sinar Grafika, 1992

Prakoso, Abintoro, Pembaruan Sistem Peradilan Pidana Anak, Yogyakarta, Aswaja Pressindo, 2016,

Prodjowikoro, Wirjono, Asas-Asas Hukum Pidana di Indonesia, 2009, Bandung: Refika Aditama.

Soekito, Sri Widoyati Wiratmo, Anak dan Wanita dalam Hukum, Yogyakarta, Liberty, 2008,

Mertokusumo, Sudikno, Mengenal Hukum, Yogyakarta, Liberty, 2005

Sholehuddin, M, Sistem Sanksi dalam Hukum Pidana, Grafindo Persada, Jakarta, 2004.

Soesilo,R, Kitab Undang-Undang Hukum Pidana (KUHP) Serta Komentarkomentarnya Lengkap Pasal demi Pasal, Bogor, Politeia, 1996

Sudarto, Hukum dan Pidana , 1986, Bandung: Alumni.

Wahid, Abdul dan Muhammad Irfan, 2011, Perlindungan Terhadap Korban Kekerasan Seksual, Bandung: Refika Aditama
Waluyo, Bambang, Viktimologi perlindungan korban \& saksi, Jakarta, Sinar Grafika, 2018

Undang-Undang Dasar Negara Republik Indonesia Tahun 1945.

Undang-undang Nomor.1 Tahun 1946 tentang Kitab Undang-undang Hukum Pidana (KUHP).

Undang-undang Nomor.8 Tahun 1981 tentang Kitab Undang-Undang Hukum Acara Pidana (KUHAP).

Undang-Undang Nomor 35 Tahun 2014 Tentang Perubahan Atas UndangUndang Nomor 23 Tahun 2002 Tentang Perlindungan Anak.

Undang-Undang Nomor. 11 Tahun 2012 Tentang Sistem Peradilan Pidana Anak. 